\title{
Perspectives in using shorebird counts for assessing long-term changes in wader numbers in the Wadden Sea*
}

\author{
Cor J. Smit \\ Research Institute for Nature Management; P.O. Box 59, 1790 AB Den Burg, \\ The Netherlands
}

\begin{abstract}
Over the past 20 years, a tradition has developed in western Europe of carrying out shorebird surveys in estuaries. These counts are mostly conducted by amateur ornithologists, usually well acquainted with the area in which they are active. The results of these surveys are well reproducible for at least the abundant species, and information is available on the size of the errors which occur. In several parts of Europe, shorebird surveys have been carried out long enough to allow trend analysis of population size. Four examples from Great Britain demonstrate that monitoring schemes may also be used for management purposes, especially if combined with specific research projects. Long-term shorebird surveys can be used not only for simple analysis of trends in bird numbers, but also to provide a deeper understanding of the functioning of the ecosystem. They may also act as a tool to document the effects of management activities in the area concerned. Shorebird surveys in the Wadden Sea have not only revealed the extremely large importance of the area, especially for waders, but also show that different areas are exploited in different ways. They have also provided data on changes in bird numbers throughout the year. Apart from the counts carried out in January, the frequency of counts in most areas in the Wadden Sea has been too low to allow the results to be used for monitoring purposes. In an area as large as the Wadden Sea, some sites, often supporting large numbers of birds, may not always be covered during simultaneous surveys. This may seriously affect the completeness of the count. The best way to overcome this problem is to calculate index values, using only those sites which have been surveyed in successive years. Two monitoring schemes are proposed which may be effective in providing relevant information for management purposes.
\end{abstract}

\section{INTRODUCTION}

Coastal wetlands throughout the world are threatened in many ways. These threats range from a few large-scale human activities having irreversible effects (like embankments, the construction of causeways, and sea level rise as a result of the greenhouse effect) to a large variety of human activities only having local and/or reversible effects on the ecosystem (Smit et al., 1987). Most wader species are migratory for part of the year, and some migrate over very large distances. During migration these birds exploit wetlands to undergo moult or to fatten up for a further flight (Piersma, 1987). This implies that human activities may affect a much larger number of birds than those present at a

- Presented at the VI International Wadden Sea Symposium (Biologische Anstalt Helgoland, Wattenmeerstation Sylt, D-2282 List, FRG, 1-4 November 1988) 
specific moment. Human activities, for instance, can negatively affect food intake at a stopover site in temperate areas and may directly affect the building up of fat reserves for a long-distance flight to winter quarters in West Africa, eventually leading to lower survival or smaller numbers in the wintering areas.

Counts of shorebirds (defined here as birds from estuarine habitats, i.e. cormorants, grebes, ducks, geese, waders, gulls and terns) are a useful tool to determine the number of birds at a specific site. The results are well reproducible for at least the abundant species, and information is available on the size of the errors which occur (Rappoldt et al., 1985; Prater \& Lloyd, 1987). Despite the effectiveness of shorebird counts in determining bird numbers, the consequences of human activities are often difficult to measure. Bird numbers following embankments in the Tees, for instance, were difficult to interpret because of interactions between species (Evans, 1981). "Natural" fluctuations in bird numbers between years (Smit \& Wolff, 1981) and the apparent possibilities of at least some birds to compensate for area loss (van Latesteijn \& Lambeck, 1986) make interpretations even more difficult. In order to understand the consequences of human activities more fully, additional information should be collected, next to information on bird numbers, on how migratory birds are exploiting the available wetlands. For birds using the East Atlantic flyway (Smit \& Piersma, 1989), this implies that information should be available from a considerable number of wetlands in northern Europe and West-Africa from as far north as northern Norway and southern Greenland (for instance for Knot Calidris canutus and Purple Sandpiper Calidris maritima) to as far south as the Republic of South Africa (for instance for Knot and Sanderling Calidris alba).

Shorebird counts can be a very useful tool in determining whether wetlands still fulfil the needs of the birds. In this paper, the results of some of these counts and some examples of their possible application will be shown. Additionally, some comments will be made as to whether the available data for the Wadden Sea can be used successfully. Finally, some recommendations will be made on how to set up monitoring schemes which may provide useful data for management purposes in the Wadden Sea.

\section{EXAMPLES ON THE POSSIBLE USE OF A MONITORING SCHEME BASED ON WADER COUNTS}

In the past, shorebird counts in the Wadden Sea have been used frequently to document the value for birds of specific parts of the area, e.g. the salt marshes and mudflats in Friesland (Zegers, 1975), Dollard (Bergman \& Dankers, 1978), Leybucht (Dahl \& Heckenroth, 1978) and Nordstrander Bucht (Schultz, 1981). Apart from the case of Brent Goose Branta bernicla, shorebird surveys have been used only in a few cases for questions related to the management of the area. Some examples are studies on the effects of hunting (e.g. Meltofte, 1982), the conditions for the construction of a natural gas exploitation platform (Oranjewoud, 1984), and the route of an oil transport pipeline (de Vlas, 1981). Studies from Great Britain show that monitoring schemes can be effective in answering questions related to nature management, especially if combined with additional, more specific studies. A well-functioning monitoring scheme may give the first hint that there are abberations from the normal pattern. The fact that all examples come from Great Britain is mainly due to the older tradition of shorebird surveys, in combination with more complete coverage in the course of the year. Ducks and geese have been 
monitored in Great Britain from the 1950s, waders from 1969 onwards. The wader scheme has been set up and is co-ordinated by the British Trust for Ornithology (BTO). It includes approximately 120 discrete estuaries, most of these covered 4-5 times annually (Prŷs-Jones \& Kirby, 1987).

Disturbance of high tide roosts on the Dee (based upon Mitchell et al., 1988)

Mid-winter wader counts on the Dee estuary close to Liverpool from 1975/76 to 1984/ 85 showed a dramatic decline in numbers for Bar-tailed Godwit (Limosa lapponica) and Knot (Fig. 1). In the same period; the total population of Bar-tailed Godwits wintering in Great Britain increased whereas Knot numbers went down, the national decrease of the latter species, however, being far less pronounced than the decrease on the Dee. In the same period, both Bar-tailed Godwit and Knot numbers in the nearby Alt estuary increased, an increase fully compensating for the decrease on the Dee. Additional observations have shown that intensive disturbance on the Dee high tide roosts, mainly by dogs, horseriders and walkers, has forced the birds to change their roosting sites from the Dee to the Alt estuary. Since both species still use the traditional feeding grounds on the Dee, this implies an extra $40-\mathrm{km}$ round-trip between feeding grounds and roosts for

Bar-tailed Godwit
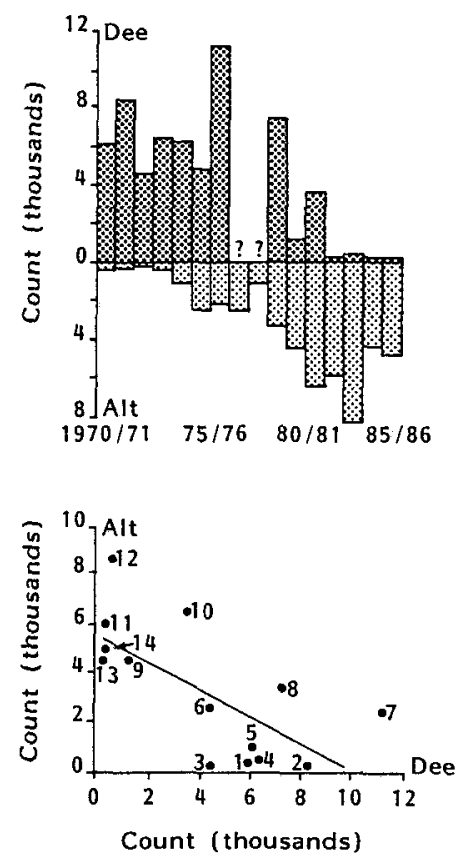

Knot
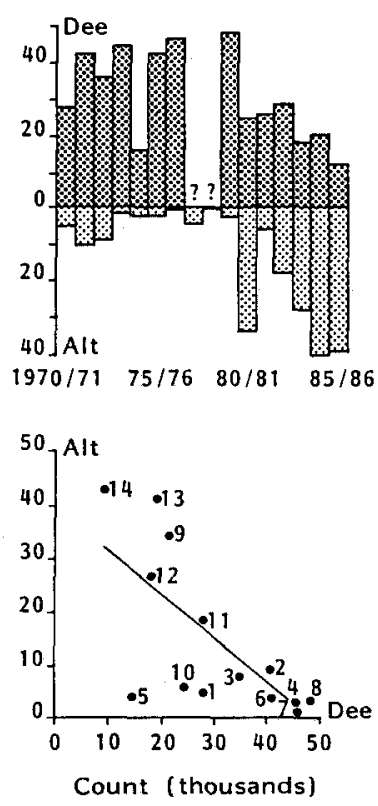

Fig. 1. Changes in numbers of Bar-tailed Godwits and Knot in peak midwinter counts on the Dee and Alt estuaries (United Kingdom) and the peak midwinter counts on the Dee plotted against peak midwinter counts an the Alt. Code numbers refer to the winters: $1970 / 71=1,1985 / 86=14$. Both for Bar-tailed Godwit and Knot there is a significant negative correlation $(P<0.01)$ (from Mitchell et al., 1988) 
Knot on each tidal cycle. This equals an extra energetical demand of $7 \%$ of the daily energy expenditure for one round-trip flight. The effects for Bar-tailed Godwit are less severe because this species traditionally uses different feeding grounds. The impact of the extra energy demand is still difficult to evaluate.

Dunlin Calidris alpina numbers and the spread of Cord grass Spartina anglica (based upon Goss-Custard \& Moser, 1988)

Numbers of Dunlin wintering in the British Isles, the Netherlands and France have decreased considerably since 1973/74. This decrease has been most conspicuous in the British Isles where numbers have approximately halved. There are very considerable differences between estuaries, numbers remaining stable in some and decreasing in others (Fig. 2). When ranking the most important estuaries in order of the spread of Spartina, Dunlin appear to have decreased most severely in estuaries showing the largest Spartina spread (Fig. 3). These data suggest that Dunlin have been displaced from
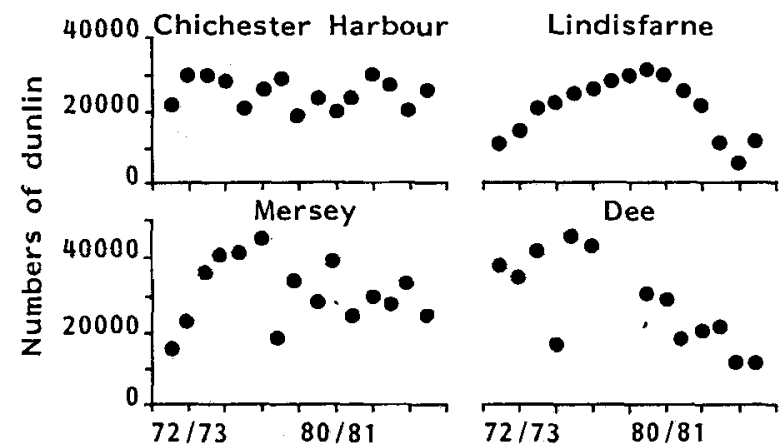

Fig. 2. Peak numbers of Dunlin in 4 estuaries in the United Kingdom during the winters $1971 / 72$ to 1984/8.5 (from Goss-Custard \& Moser, 1988)

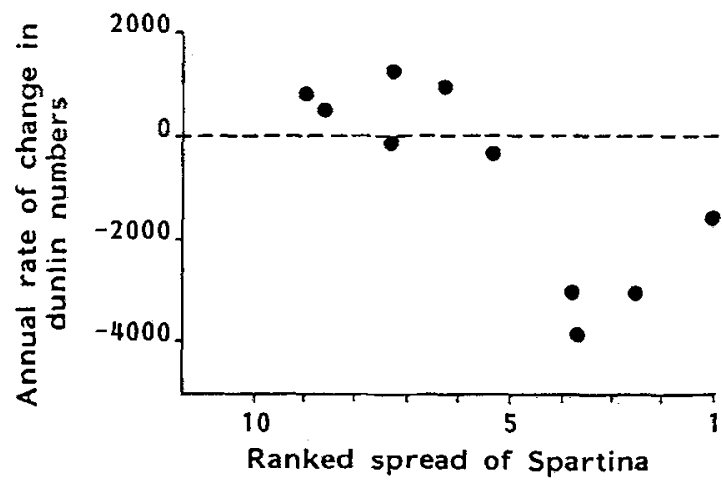

Fig. 3. Annual rate of change in Dunlin numbers in winter in the ten most important estuaries for Dunlin in the United Kingdom against ranked change in Spartina anglica abundance over the same period from $1977 / 78$ to $1984 / 85$ (from Goss-Custard \& Moser, 1988) 
estuaries where Spartina has spread. There are no indications that they have been able to re-establish themselves elsewhere in Britain or in the neighbouring countries. Dunlin are considered vulnerable to Spartina spread. In order to replenish their energy need in winter they have to feed almost continuously throughout the tidal cycle. This applies to adults, and even more so for the less experienced juvenile birds. For this reason, Dunlin intensively use the higher parts of the tidal flats at the beginning and the end of each low tide period, areas primarily affected by Spartina spread. As a result of the present Dunlin case, methods are under study to counteract the negative effects of Spartina spread.

Wader numbers and pollution in the Clyde estuary (based upon Furness et al., 1986)

From the middle of the 19th century onwards, the Clyde estuary (Scotland) was heavily polluted by domestic sewage and industrial wastes. High organic pollution was still going on in the early 1970s, leading to high densities in a small number of intertidal invertebrate species tolerant of organic pollution and low $\mathrm{O}_{2}$ levels, which provide rich feeding for several wader species. Recent success in reducing the input of organic pollutants may have led to decreasing numbers of waders, a pattern which differed from the national trends and could not be explained by changes in the breeding habitats of the species involved (Fig. 4). The decrease was most pronounced in species feeding mainly

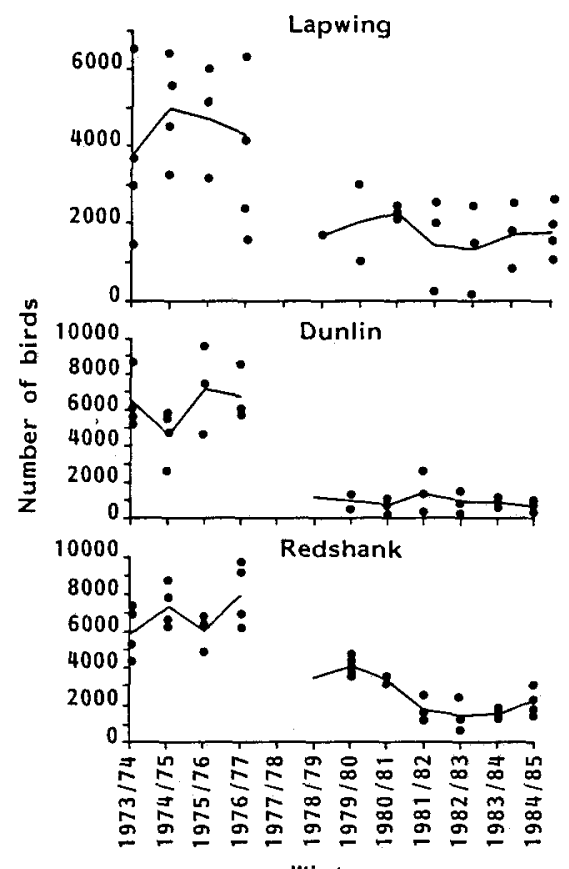

Fig. 4. Results of wader counts for Lapwing Vanellus vanellus, Dunlin Calidris alpina and Redshank Tringa totanus in the Clyde estuary (Scotland). Dots represent counts from November to February, lines the mean winter numbers (from Furness et al., 1986) 
on Corophium volutator. Lower bird numbers were explained by reduced organic pollution, which is believed to have caused a reduction of the stocks of the main prey organisms or to have led to higher $\mathrm{O}_{2}$ levels, allowing fish to compete more intensively with waders for the available prey.

Limits to the numbers of Grey Plovers Pluvialis squatarola on British estuaries (based upon Moser, 1988)

The numbers of Grey Plovers wintering in British estuaries have been found to increase steadily over the past 17 years (see Fig. 8). Elsewhere in western Europe, either the same has happened or numbers have remained stable, so the increase in Britain cannot be explained as a shift from wintering quarters at close distance. Though there are no reliable data available on the situation in the breeding areas, an increase in the breeding population is the most likely explanation for this phenomenon. Figure 5 shows that the national increase could be noted in particular estuaries (like the Mersey), whereas at other sites numbers remained stable or increased only slightly (like Chichester Harbour). This suggests that sites are filled up sequentially, the most preferred sites already being fully exploited by Grey Plovers even when population numbers are still low. Initially less preferred areas seem to be filled up according to a certain preference. There seems to be an upper limit (at $<1$ Grey Plover/ha) to the density of Grey Plovers on individual estuaries (Fig. 6). There is a tendency that estuaries with higher average January temperatures are preferred to colder areas, but as a whole the factors behind this phenomenon remain obscure. Specific research on the sequential filling up of estuaries, in combination with the present data, will provide important information on the mechanisms behind the carrying capacities of estuaries for birds. A basic understanding of these processes is essential to comprehending the effects of loss of tidal mudflats on shorebirds.
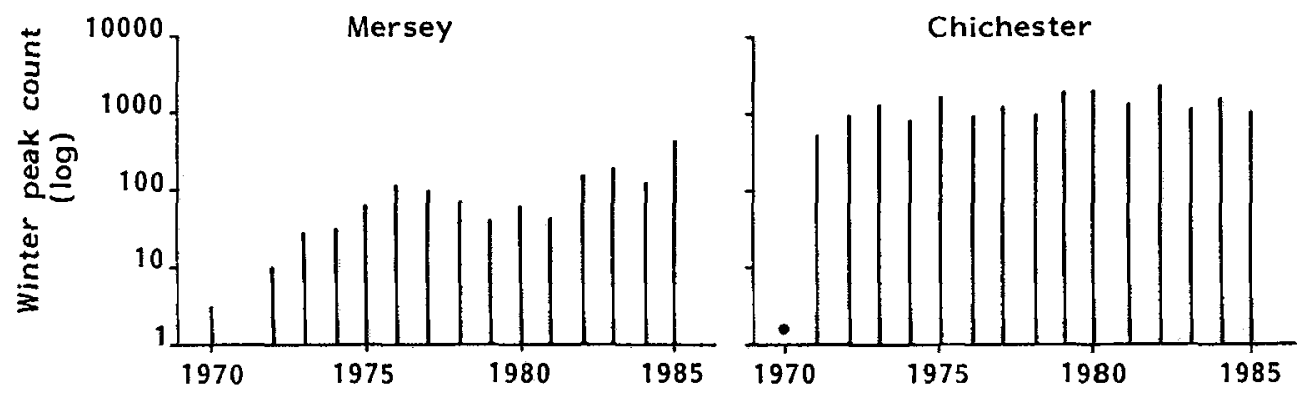

Fig. 5. Winter peak numbers of Grey Plovers on the Mersey and in Chichester Harbour (United Kingdom) in 1970/71-85/86 (from Moser, 1988)

\section{AN INDEX FOR WINTERING WADER NUMBERS IN GREAT BRITAIN}

The described examples of the possible use of results from wader surveys in midwinter were based on unrevised results of counts. The only adaption was the use of maximum figures for each winter (data from November-February). By working up the 


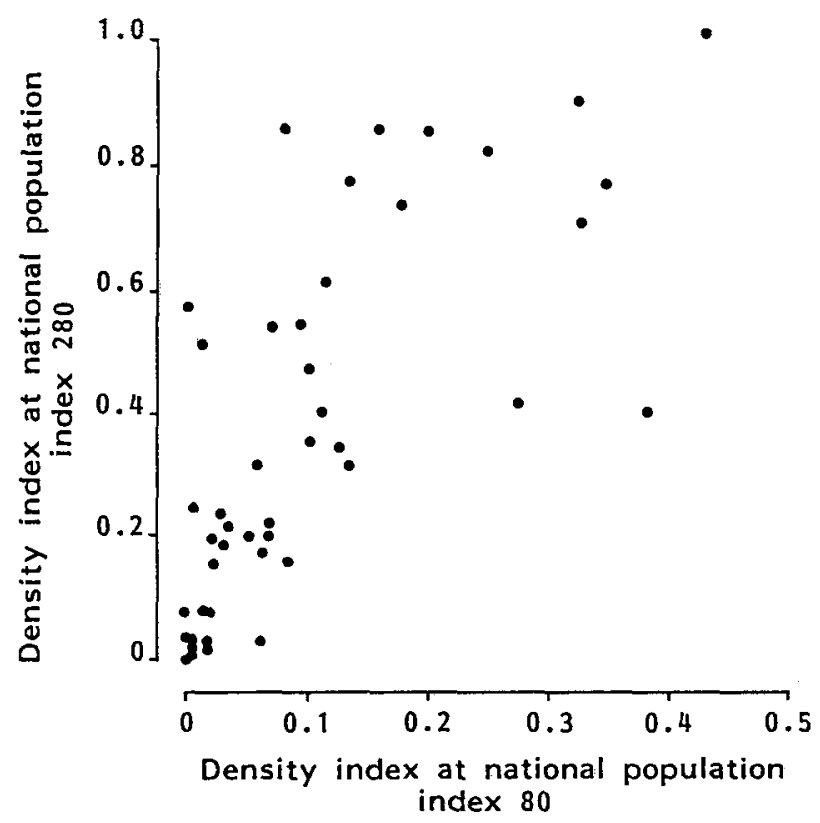

Fig. 6. Comparison of density indices (birds/ha) of Grey Plovers on 45 estuaries in the United Kingdom at low (winter peak count index $=80$ ) and high (winter peak count index $=280$ ) population levels (from Moser, 1988)

data in this way, possible mistakes, for instance due to occasional incomplete coverage, could be accounted for. For single sites this is a reliable method and there is no need for more complicated methods. An analysis of the data on large areas, composed of many sites, involves more complicated methods of data handling. When calculating the national total for Great Britain or the overall total for the international Wadden Sea area, for instance, there are always some sites which cannot be covered during the census, either due to the weather situation or to logistic problems. The size of these areas varies greatly between counts. Consequently, the number of birds not included in the total figure varies as well. Some of these sites may hold large numbers of birds. For this reason, trends in numbers in Great Britain are generally expressed as an index in which the results for all sites, surveyed in successive years, are combined with an index of the previous year (cf. Owen et al., 1986; Moser, 1988). Indices provide a more reliable picture of bird numbers actually present throughout the country. A drop in the national totals, for instance in Oystercatcher Haematopus ostralegus totals from Great Britain in 1979 (Fig. 7) is not an effect of fewer birds being present but is merely due to an incomplete count. For the calculation of this index the following equation is used:

$$
\text { index year } 2=\frac{\text { number year } 2}{\text { number year } 1} \cdot \text { index year } 1
$$

where "number" refers to the number of birds from sites which have been included in the counts of both years. 


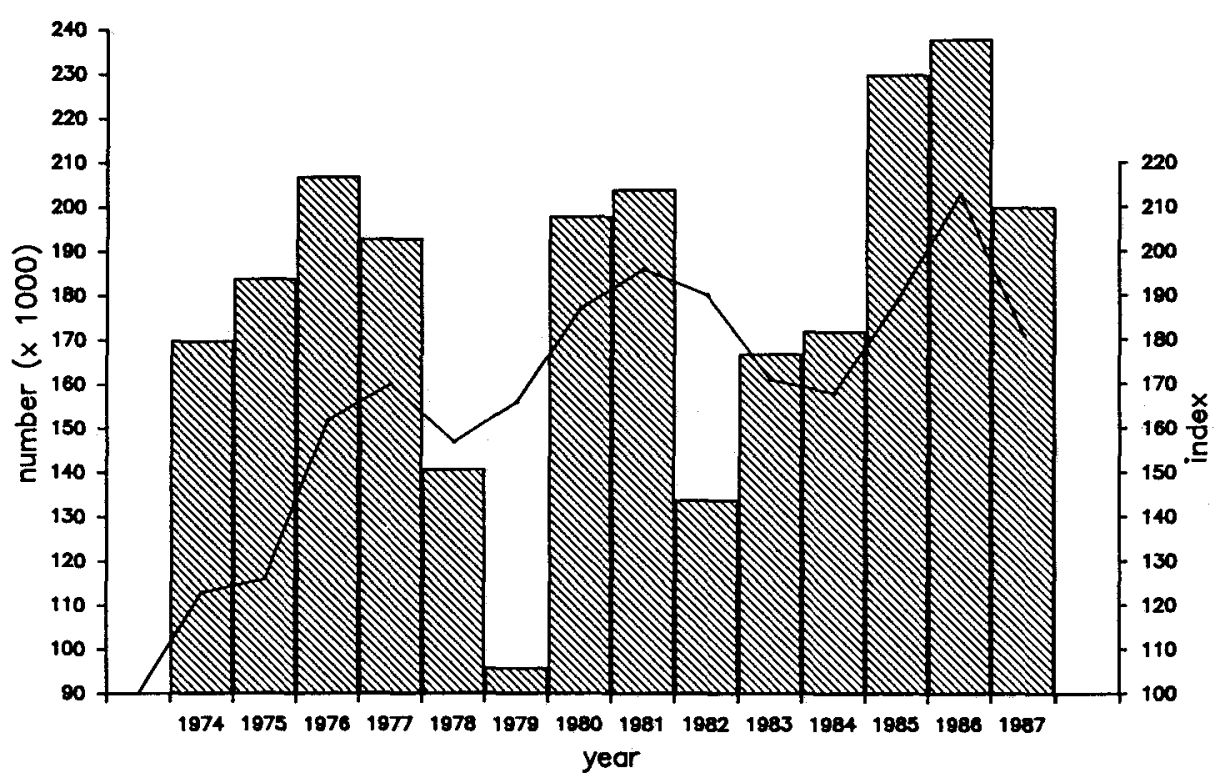

Fig. 7. January numbers (columns) and index values (line) for Oystercatchers in the United Kingdom from 1974-87. Data derived from annual reports of the Birds of the Estuaries Enquiry and Prŷs-Jones \& Kirby (1987)

Indices for some species are shown in Figure 8, Grey Plover and Dunlin figures showing patterns already discussed. Oystercatchers 'gradually increased in numbers. This increase corresponds with an increase in the size of the breeding populations in the Netherlands und Britain (Smit \& Piersma, 1989). The factors behind this increase largely remain obscure. Higher wintering numbers could be a result of larger breeding populations, which would mean that the carrying capacity in the wintering areas had not yet been reached. On the other hand, higher breeding bird populations could be an effect of improved conditions on the wintering grounds, for instance due to higher food stocks. Indeed, several benthic species in the Wadden Sea appear to have increased. A causal relation cannot be proved but this increase can be an effect of higher primary production, due to eutrophication of the Wadden Sea water (Beukema \& Cadée, 1986).

The index for Knot in Great Britain has been rather stable over the past 13 years (1975-1987) but is considerably lower than figures counted previously. A strong decrease in Knot numbers has also been found elsewhere in Europe. The west European wintering totals decreased from 609000 in the early part of the 1970s to 345000 (Smit \& Piersma, 1989), in spite of more complete surveys in recent years. The decrease is particularly striking in France (from 110000 to 19000 ), Britain (from 350000 to 218000 ) and Ireland (from 55000 to 30000 ). The reasons behind this decline are not known, but may be an effect of a series of bad breeding seasons, possibly in combination with habitat loss in the wintering areas (Green et al., 1977; Pienkowski \& Evans, 1985). 


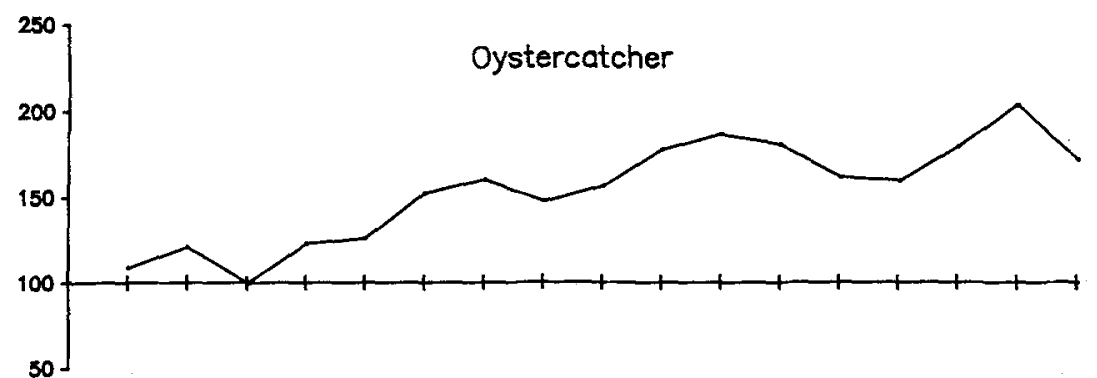

19711972197319741975197619771978197919801981198219831984198519861987

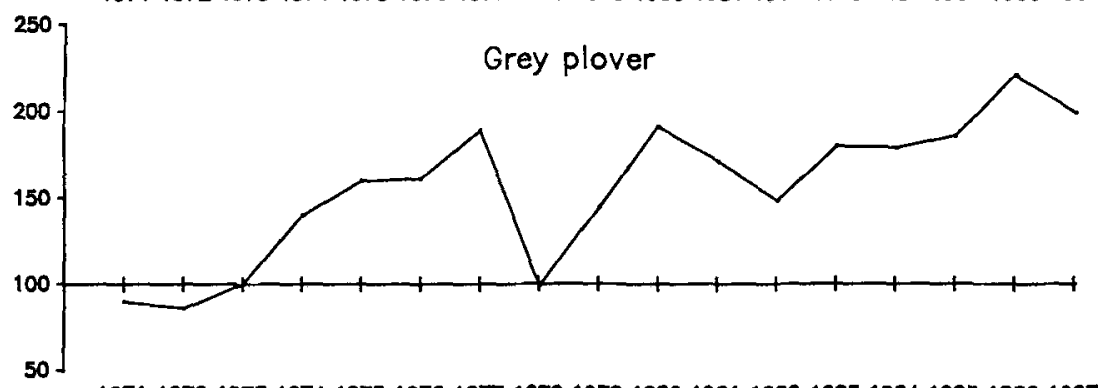

19711972197319741975197819771978197919801981198219831984198519861987
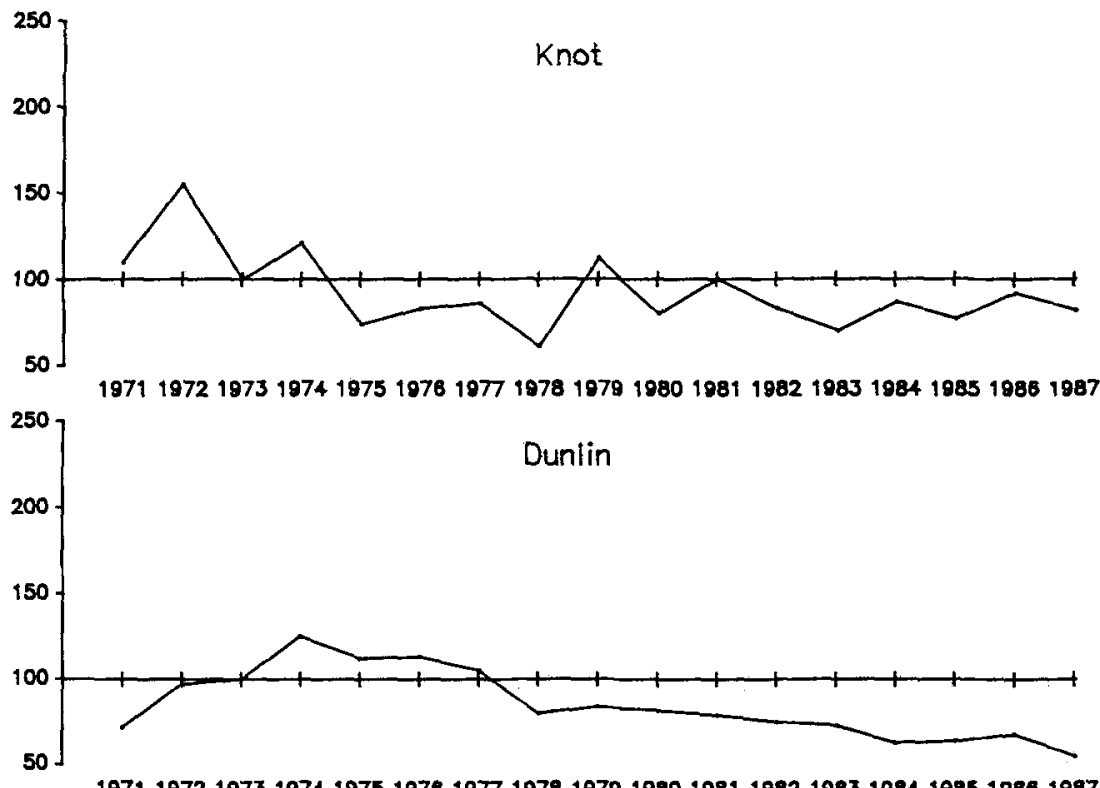

Fig. 8. Indices of the numbers of 4 wader species present in mid-winter in Great Britain (from PrŷsJones \& Kirby, 1987) 

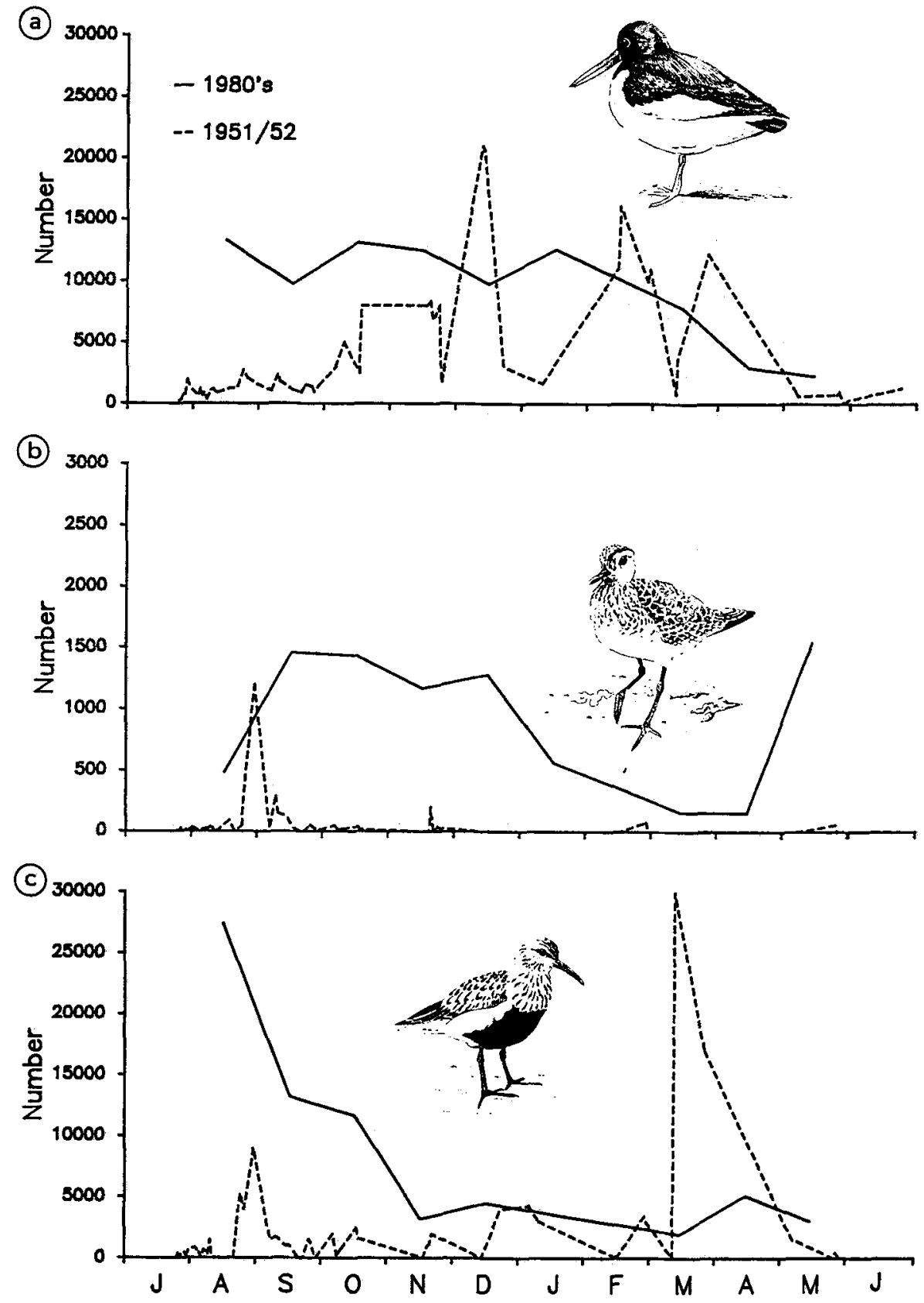

Fig. 9. Oystercatcher (a), Grey Plover (b) and Dunlin (c) numbers at the Boschplaat (Terschelling) throughout the 1951/52 season (Mörzer Bruyns \& Braaksma, unpubl.) and mean data per month for the 1980 s in the same area (unpubl. data D. A. Jonkers, A. L. Spaans, H. Smit \& F. Zwart) 


\section{SHOREBIRD COUNTS IN THE INTERNATIONAL, WADDEN SEA AREA}

The first estimate of the total number of birds present in the Dutch part of the Wadden Sea was made in October 1931 (van Oordt, 1932), from an aerial survey of the northern part of the area, including the island of Griend. Extrapolating for numbers along the mainland coast, van Oordt arrived at $500000-600000$ birds, but this figure is difficult to compare with recent data. More or less frequent surveys of parts of the Wadden Sea started in the 1960s. These counts were mostly carried out by amateur ornithologists, except for those in bird sanctuaries where they were carried out mostly by guards (for instance at Griend, Engelsmanplaat, Rottumerplaat, Rottumeroog, Memmert, Lütje Hörn, Wangerooge, Oldeoog, Mellum, Knechtsand, Trischen and Jordsand). In two areas in the Dutch part of the Wadden Sea (the Boschplaat on the eastern part of Terschelling and the island of Vlieland), wader and waterfowl counts were carried out in 1951/53 and 1953/56 respectively. The results of these surveys have been published as maximum counts per month for each species (Terschelling : Mörzer Bruyns \& Braaksma, 1954; Vlieland: Rooth, 1960 ), but fortunately the original figures from the Terschelling counts are available as well (Visser, pers. comm.). A comparison of the 1951/52 data and those from the 1980s shows striking differences for several species (Fig. 9). For the Oystercatcher the wintering figures are comparable, but especially in summer and autumn Oystercatchers have strongly increased. Grey Plovers are much more numerous throughout the year. For Dunlin the picture is more complex. In the 1980 s, Dunlins seem to be more numerous in autumn and less numerous in spring. At present, Dunlins are relatively numerous in autumn in the area close to the Dutch Wadden Sea islands and less so along the mainland coast, whereas in spring they are more evenly spread throughout the area (Boere \& Smit, 1981a). The data for Dunlin in Figure 9 suggest that these differences in migration peaks between the islands and the mainland coast may have altered during the past 30 years.

The first simultaneous counts in the Dutch Wadden Sea were organized in 1963, 1966 and from 1972 onwards (data summarized in Smit \& Wolff, 1981). In Niedersachsen, complete simultaneous counts have only rarely been achieved (Knief, 1982). In Schleswig-Holstein, simultaneous counts started in 1965, though the area generally could not be fully covered. In the following years, a rather complete picture developed of wader numbers roosting along the mainland coast and on the larger inhabited islands. Incidentally, a more complete picture could be achieved through additional aerial surveys (Busche, 1980). In the Danish part of the Wadden Sea, simultaneous surveys started in 1969, but became more frequent in 1974 (Meltofte, 1980). From 1979 onwards, monthly aerial surveys have been carried out, ground surveys run at a frequency of three to four annually (Laursen et al., 1987). A much longer series of counts is available for the Tipperne reserve (in Ringkøbing Fjord), an area only $20 \mathrm{~km}$ north of the Wadden Sea (Meltofte, 1987). The latter data demonstrate the effects of a change from salt to fresh water, succession of vegetations and changes in management policies on the species composition and the numbers of birds in the area.

Attempts to survey simultaneously the whole international Wadden Sea area started in September 1973 (Prater, 1974), for the first time demonstrating the enormous importance of the Wadden Sea by yielding approximately 2 million waders. Since 1981, approximately 2-3 simultaneous annual surveys have been made each year in the international Wadden Sea area. The first results of these surveys were published quite 
soon after that (Smit, 1982). A combination of all existing shorebird counts in the international Wadden Sea area has yielded in the meantime a fairly good picture of bird numbers throughout the year and of the distribution of species (Busche, 1980; Meltofte, 1980; Smit \& Wolff, 1981).

\section{AN INDEX FOR WADER NUMBERS IN THE DUTCH PART OF THE WADDEN SEA}

As in Great Britain, fluctuations in shorebird numbers in the whole Wadden Sea area will be better reflected by an index than by unadjusted counts. As yet, there is no tradition of calculating indices for waders or waterfowl in the Wadden Sea area. Figure 10 shows preliminary results for 3 wader species from the Dutch part from 1974-84. Apart from some trends which are comparable with data from Great Britain, there are considerable differences. Most obvious is the large decrease in Grey Plover numbers, caused by massive departure due to a severe cold spell in January 1982. This effect is less pronounced in the other two species but still noticeable. Due to lower winter temperatures in the Wadden Sea, massive departures will occur more often than in British estuaries. Figure 10 shows quite clearly that the results of the counts carried out in the Dutch part of the Wadden Sea in the past can be used for index calculations, at least for some abundant species. The results will improve when more data are included (by using more sites) and will become more interesting when using data covering a longer period.

January surveys have been carried out at many sites in the Wadden Sea since the early 1970 s. Surveys covering other months apart from the mid-winter month of January have been carried out less frequently (i.e. in some years a spring survey has been organized in April, in other years in May). Consequently, these data cannot be used for comparing bird numbers between years or for calculating trends through indices. Exceptions to this rule are probably the frequent counts which have been conducted in bird sanctuaries in spring and summer, and the aerial survey programme in the Danish Wadden Sea. Special programmes set up to monitor the annual peak numbers of, for instance, Grey Plover or Knot require a survey around a specific date in May each year. For the two Knot populations present in the Wadden Sea, these data will be two weeks apart (Prokosch, 1988), demonstrating that if there is a desire to survey the peak numbers, frequent counts are necessary. Due to logistic problems, it is not possible to organize frequent simultaneous counts in the whole Wadden Sea throughout spring and autumn. For this purpose, a separate monitoring scheme will have to be developed. Such a scheme would have to be set up next to less frequent simultaneous surveys which yield information on total numbers and the distribution of birds over the area.

\section{ADDITIONAL INFORMATION FROM RINGING STUDIES}

Though shorebird surveys may reveal a great deal about wader migration patterns, site use and trends in numbers, there are obvious limitations as to what they can reveal. Additional field studies, focussing on specific questions, may help to complete the picture. For several wader and goose species it is possible to get insight into the annual chick production by simply determining the adult-juvenile ratio in autumn in the field. There appear to be considerable differences between sites that are not yet fully understood (Furness \& Baillie, 1981; Pienkowski \& Evans, 1985), also showing that adults and 


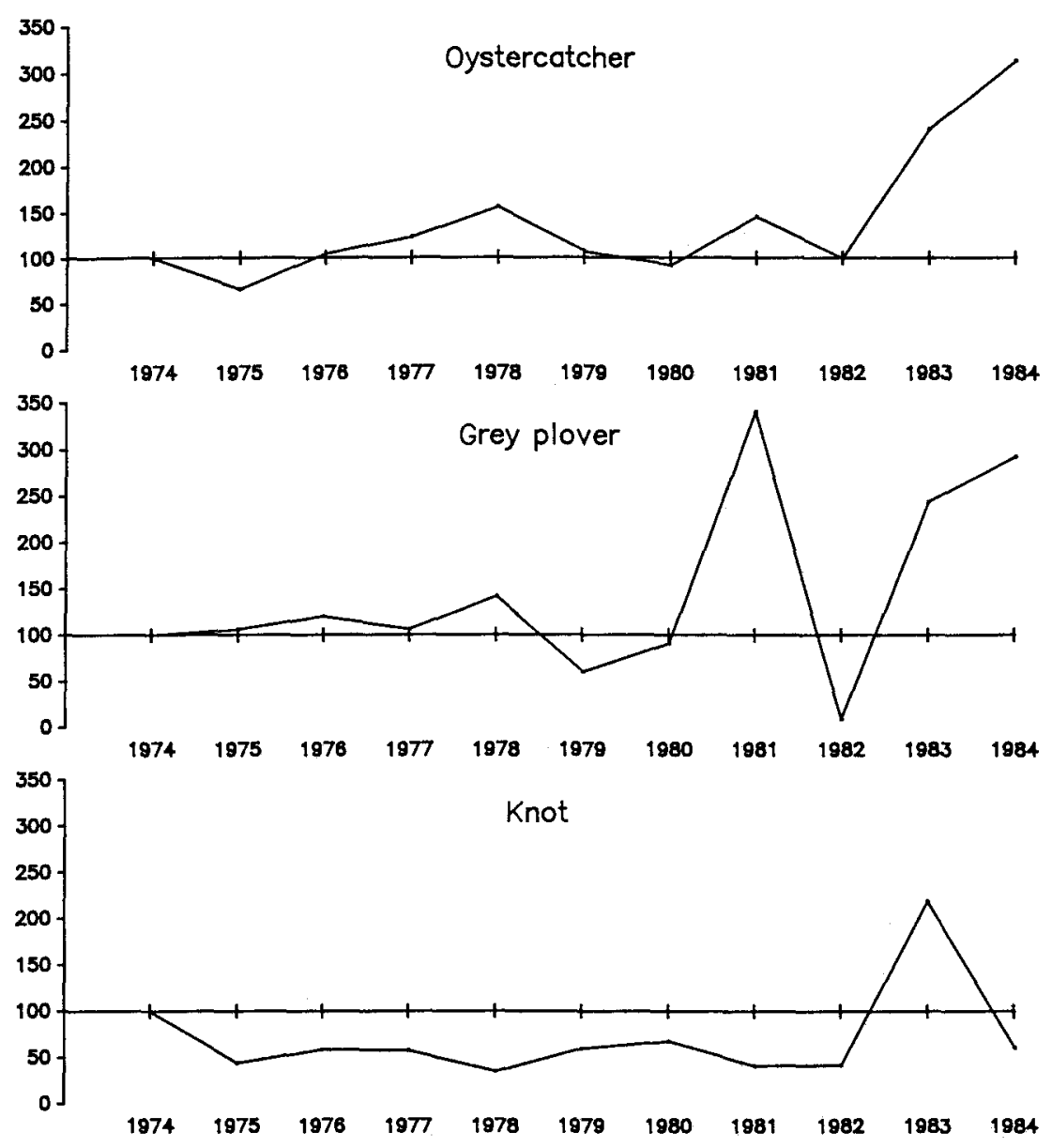

Fig. 10. Preliminary indices on the numbers of Oystercatcher, Grey Plover and Knot, based on data from Texel, Terschelling, Ameland, Balgzand, and the Friesland and Groningen mainland coast (data IWRB Wader Research Group, largely supplied by counts organized by P. Zegers)

juveniles often use different areas. This phenomenon has also been demonstrated in the Wadden Sea (van der Have et al., 1984; Swennen, 1984). The annual chick production can be highly variable between years (Boere, 1974; Furness \& Baillie, 1981; Summers \& Underhill, 1987), which may be important information when counts reveal a dramatic drop in numbers of certain species (cf. the example for Knot on p. 374). Catching and ringing programmes, in combination with biometrical research on the captured birds, help to show the origin of the populations, the composition of the bird populations, and also help to document more fully how these birds exploit these areas. They yield information on the following topics:

- the presence of relatively rare species (Jukema, 1979)

- the adult-juvenile ratio and the way different age classes are using a specific area (van der Have et al., 1984) 
- the presence of subspecies which cannot be distinguished in the field (e.g. for Redshank in Boere \& Smit; 1981b)

- the male-female ratio (Prokosch, 1988)

- the progress of moult (Boere, 1976) and eventual changes in the use of an area as a moulting place

- the progress of pre-migratory fattening (e.g. Prokosch, 1988) and differences between years

- survival rates (Metcalfe \& Furness, 1985)

- turn-over rates (Kersten \& Smit, 1984)

- changes in site fidelity (Symonds et al., 1984; Metcalfe \& Furness, 1985), for instance due to human activities or habitat changes

- inter-estuarine movements (Pienkowski \& Pienkowski, 1983)

- the use of bird feathers for specific projects, e.g. for monitoring levels of heavy metals (Goede \& de Bruin, 1984).

To allow for comparison between years, catching and ringing programmes should ideally have the character of a monitor programme, using constant catching techniques and input of catching efforts.

\section{PROSPECTS FOR THE FUTURE}

The standard shorebird counts in the international Wadden Sea area taken in months other than January will not be adequate enough to document long-term changes in bird numbers. Exceptions to this general rule could be, perhaps, the data supplied by aerial surveys in the Danish Wadden Sea, as well as the data from spring and summer from bird sanctuaries and some areas where long series of frequent counts are being carried out (i.e. Balgzand, Schiermonnikoog, Dollard, Elisabeth-Aussengroden, Langli). In general, the international counts have been too irregular to fit monitoring purposes. An exception to this rule are counts of Brent Goose, for which species specific annual counts have been organized in May, when peak numbers are present in the Wadden Sea (Ebbinge et al., 1981). For waders, a specific approach such as that applied in the case of Brent Goose is not possible because migration peaks in the Wadden Sea differ from species to species, and changes in bird numbers in the Wadden Sea may occur throughout the year (cf. Fig. 9). In order to partly avoid this problem, a series of frequent counts in selected areas should be set up throughout (most of) the year. These counts should preferably be carried out by professional or by well trained and well motivated amateur ornithologists, in order to guarantee complete surveys over a long period. The sites chosen should preferably be representative of larger parts of the Wadden Sea. Since every site has its own characteristics, this condition is probably not very realistic. Therefore, a variety of sites should be chosen. It is important to include, next to some small areas which are relatively easy to count, some larger areas holding larger numbers of birds, on the mainland as well as on the islands. A scheme like this has been in practice since early 1987 in SchleswigHolstein (Prokosch, pers. comm.). These counts are carried out around each spring tide, i.e. at a frequency of approximately 15 days. This type of scheme can be adapted to cover the whole Wadden Sea area. It is difficult to predict how many plots it will require to satisfactorily analyse trends in numbers. This will largely depend on the numbers of each particular species and its distribution throughout the area. 
Next to information on the fate of these birds in the Wadden Sea itself, a monitoring scheme as proposed here will provide information on, or call attention to, developments elsewhere in the flyway area. For the Wadden Sea, several major developments may be expected for the coming years, e.g. sea level rise, an ongoing pollution of sea water with persistent chemicals, a possibly decreasing eutrophication, or a further increase of human activities. Shorebirds are relatively easy to monitor. As top-predators in food chains they represent potentially good indicator organisms. A preliminary analysis of the available shorebird counts in the Wadden Sea indicates that only a systematically organized scheme, preferably in combination with a catching and ringing programme, will be able to document changes in bird numbers. The information it will provide is essential for successfully determining the effects of management policies. Additionally, a monitoring scheme of this kind will provide scientifically interesting data which will allow us to understand better the rôle of shorebirds in the ecosystem, and the reasons for their occurrence in the present numbers.

Acknowledgements. Much of the information in this paper has been collected by hundreds of anonymous wader enthusiasts, often in their spare time and paying for their own travelling expenses. Their contribution is paramount, and cannot be praised highly enough! J. Brouns, K. Laursen, M. Moser, G. Visser, W. Wolff, P. Zegers and two anonymous referees commented on the manuscript and polished the English. G. Visser discovered the original data from the Boschplaat from the 1950s and made the information available for this paper. Typing was cheerfully carried out by $M$. Scholl; figures were drawn by $A$. Griffioen.

\section{LITERATURE CITED}

Bergman, M. \& Dankers, N., 1978. De ecologische consequenties van het omleggen van de Eems door de Dollard. Research Institute for Nature Management, Texel, $128 \mathrm{pp}$.

Beukema, J. J. \& Cadée, G. C., 1986. Zoobenthos responses to eutrophication of the Dutch Wadden Sea. - Ophelia 26, 55-64.

Boere, G. C., 1974. Was 1974 een slecht broedseizoen voor sommige steltlopersoorten? - Levende Nat. 77, 217-220.

Boere, G. C., 1976. The significance of the Dutch Waddenzee in the annual life cycle of arctic, subarctic and boreal waders. Part 1. The function as a moulting area, - Ardea 64, 210-291.

Boere, G. C. \& Smit, C. J., 1981a. Dunlin (Calidris alpina L.). In: Birds of the Wadden Sea. Ed. by C. J. Smit \& W. J. Wolff. Balkema; Rotterdam, 157-169. (Rep. Wadden Sea Working Group, 6.)

Boere, G. C. \& Smit, C. J., 1981b. Redshank (Tringa totanus L.). In: Birds of the Wadden Sea. Ed. by C. J. Smit \& W. J. Wolff. Balkema, Rotterdam, 195-206. (Rep. Wadden Sea Working Group, 6.)

Busche, G., 1980. Vogelbestände des Wattenmeeres von Schleswig-Holstein. Kilda, Greven, $157 \mathrm{pp}$.

Dahl, H. J. \& Heckenroth, H., 1978. Landespflegerisches Gutachten zu geplanten Deichbaumaßnahmen in der Leybucht. - Natursch. LandschPflege Nieders. 7, 1-176.

Ebbinge, B. W., Fog, M. \& Prokosch, P., 1981. Brent Goose (Branta bernicla L.). In: Birds of the Wadden Sea. Ed. by C. J. Smit \& W. J. Wolff, Balkema, Rotterdam, 28-37. (Rep. Wadden Sea Working Group, 6)

Evans, P. R., 1981. Reclamation of intertidal land: some effects on Shelduck and wader populations in the Tees estuary. - Verh. orn. Ges. Bayern 23, 147-168.

Furness, R. W. \& Baillie, S. R., 1981. Age ratios, wing length and moult as indicators of the population structure of Redshank wintering on British estuaries. - Ringing Migration 3, 123-132.

Furness, R. W., Galbraith, H., Gibson, 1. P. \& Metcalfe, N. B., 1986. Recent changes in numbers on the Clyde estuary and their significance for conservation. - Proc. R. Soc. Edinb. 90 (B), 171-184.

Goede, A. A. \& Bruin, M. de, 1984. The use of bird feather parts as a monitor for metal pollution. Environ. Pollut. (Ser. B.) 8, 281-298.

Goss-Custard, J. D. \& Moser, M. E., 1988. Rates of change in the numbers of Dunlin, Calidris alpina, 
wintering in British estuaries in relation to the spread of Spartina anglica. - J. appl. Ecol. 25, 95-109.

Green, G. H., Greenwood, J. J. D. \& Lloyd, C. S., 1977. The influence of snow conditions on the date of breeding of wading birds in north-east Greenland. - J. Zool. 183, 311-328.

Have, T. M. van der, Nieboer, E. \& Boere, G. C., 1984. Age-related distribution of Dunlin in the Dutch Wadden Sea. In: Coastal waders and wildfowl in winter. Ed. by P. R. Evans, J. D. GossCustard \& W. G. Hale. Cambridge Univ. Press, Cambridge, 160-176.

Jukema, J., 1979. Krombekstrandlopers langs de Friese Waddenkust. - Watervogels 4, 3-6.

Kersten, M. \& Smit, C. J., 1984. The Atlantic coast of Marocco. In: Coastal waders and wildfowl in winter. Ed. by P. R. Evans, J. D. Goss-Custard \& W. G. Hale. Cambridge Univ. Press, Cambridge, $276-287$.

Knief, W., 1982. Ergebnisse der Wasser- und Watvogelzählungen, 1980/81 in Niedersachsen und an der Westküste von Schleswig-Holstein. - Natursch. LandschPflege Nieders. 3, 1-218.

Latesteijn, H. C. van \& Lambeck, R. H. D., 1986. The analysis of monitoring data with the aid of timeseries analysis. - Environ. Monit. Assess. 7, 287-297.

Laursen, K., Maltha Rasmussen, L. \& Frikke, J., 1987. Internationale vandfugletaellinger i Vadehavet. - Dansk orn. Foren. Tidsskr. 81, 178-179.

Meltofte, H., 1980. Fugle i Vadehavet. Vadefugletaellinger i Vadehavet 1974-1978. Fredningsstryrelsen, København, $50 \mathrm{pp}$.

Meltofte, H., 1982. Jagtlige forstyrrelser af svomme- og vadefugle. - Dansk orn. Foren. Tidsskr. 76, 21-35

Meltofte, H., 1987. Vadefugle paa Tipperne, 1928-82. - Dansk orn. Foren. Tidsskr. 81, 1-108.

Metcalfe, N. B. \& Furness, R. W., 1985, Survival, winter population stability and site fidelity in the Turnstone Arenaria interpres. - Bird Study 32, 207-214.

Mitchell, J. R., Moser, M. E. \& Kirby, J. S., 1988. Declines in midwinter counts of waders roosting on the Dee estuary, - Bird Study 35, 191-198.

Mörzer Bruyns, M. F. \& Braaksma, S., 1954. Vogeltellingen in het staatsnatuurreservaat Boschplaat van $1951 \mathrm{t} / \mathrm{m}$ 1953. - Ardea 42, 175-210.

Moser, M. E., 1988. Limits to the numbers of Grey Plovers Pluvialis squatarola wintering on British estuaries: an analysis of long-term population trends. - J. appl. Ecol. 25, 473-485.

Oordt, G. J. van, 1932. Verslag van een tocht met Hr.Ms. Watervliegtuig L7 boven de Nederlandse Waddenzee op 5 oktober 1931. - A. Rep. Stichting "Vogeltrekstation Texel" 1, 25-29.

Oranjewoud B. V., 1984. Onderzoek naar overwinterende Eidereenden in de westelijke Waddenzee. Oranjewoud, Heerenveen, $38 \mathrm{pp}$.

Owen, M., Atkinson Willis, G. L. \& Salmon, D. G., 1986. Wildfowl in Great Britain. Cambridge Univ. Press, Cambridge, 613 pp.

Pienkowski, M. W. \& Pienkowski, A., 1983. WSG Project on the movement of wader populations in western Europe: eighth progress report. - Wader Study Group Bull. 37, 13-22.

Pienkowski, M. W. \& Evans, P. R., 1985. The role of migration in the population dynamics of birds. In: Behavioural ecology. Ed. by R. M. Sibley \& R. H. Smith, Blackwell, Oxford, 331-352.

Piersma, T., 1987. Hink, stap of sprong? Reisbeperkingen van arctische steltlopers door voedselzoeken, vetopbouw en vliegsnelheid. - Limosa 60, 185-194.

Prater, A. J., 1974. Wader research; coastal wader counts. - IWRB Bull. 37, 102-104.

Prater, A. J., 1981. Estuary birds of Britain and Ireland. Poyser, Calton, $440 \mathrm{pp}$.

Prater, A. J. \& Lloyd, C. S., 1987. Birds. In: Biological surveys of estuaries and coasts. Ed. by J. M. Baker \& W. J. Wolff. Cambridge Univ. Press, Cambridge, 374-403.

Prokosch, P., 1988. Das Schleswig-Holsteinische Wattenmeer als Frühjahrs-Aufenthaltsgebiet arktischer Watvogelpopulationen am Beispiel von Kiebitzregenpfeifer (Pluvialis squatarola, L. 1758), Knutt (Calidris canutus, L. 1758) und Pfuhlschnepfe (Limosa lapponica, L. 1758). - Corax $12,273-442$.

Prŷs-Jones, R. P. \& Kirby, J. S., 1987. Waders. In: Wildfowl and wader counts 1986-87. Ed. by D. G. Salmon, R. P. Prŷs-Jones \& J. S. Kirby. Wildfowl Trust, Slimbridge, 63 pp.

Rappoldt, C., Kersten, M. \& Smit, C., 1985. Errors in large-scale shorebird counts. - Ardea 73, $13-24$.

Rooth, J., 1960. Vogeltellingen op Vlieland van $1953 \mathrm{t} / \mathrm{m}$ 1956. - Limosa 33, 134-159.

Schultz, W., 1981. Forschungsvorhaben "Vogelkundliche Bedeutung der Nordstrander Bucht". SchrReihe Landesreg. Schlesw.-Holst. 12, 197-235. 
Smit, C., 1982. Wader and waterfowl counts in the international Wadden Sea area: the results of the 1980-81 season. - Wader Study Group Bull. 35, 14-17.

Smit, C. J. \& Wolff, W. J. (Eds), 1981. Birds of the Wadden Sea. Balkema, Rotterdam, 308 pp. (Rep. Wadden Sea Working Group, 6.)

Smit, C. J. \& Piersma, T., 1989. Numbers, mid-winter distribution and migration of wader populations using the East Atlantic Flyway. - IWRB spec. Publ. 9, 24-63.

Smit, C. J., Lambeck, R. H. D. \& Wolff, W. J., 1987. Threats to coastal wintering and staging areas of waders. - IWRB spec. Publ. 7, 105-113.

Summers, R. W. \& Underhill, L. G., 1987. Factors related to breeding production of Brent geese Branta $b$. bernicla and waders (Charadrii) on the Taimyr peninsula. - Bird Study 34, 161-171.

Symonds, F., Langslow, D. R. \& Pienkowski, M. W., 1984. Movements of wintering shorebirds within the Firth of Forth: species differences in usage of an intertidal complex. - Biol. Conserv. 28, $187-215$.

Swennen, C., 1984. Differences in quality of roosting flocks of Oystercatchers. In: Coastal waders and wildfowl in winter. Ed. by P. R. Evans, J. D. Goss-Custard \& W. G. Hale. Cambridge Univ. Press, Cambridge, 177-189.

Vlas, J. de, 1981. Effectenstudie pijpleiding F3-Eemshaven. Voorselectie van 3 nader to onderzoeken tracé's door de Waddenzee. Research Institute for Nature Management, Texel, $94 \mathrm{pp}$.

Zegers, P. M., 1975. Vogels. In: Noord-Friesland buitendijks. Ed. by J. Abrahamse \& H. Muntingh. Landelijke Vereniging tot Behoud van de Waddenzee, Harlingen, 36-53. 